AGNIESZKA MIODUCHOWSKA-ZIENKIEWICZ ${ }^{4}$

Instytut Psychologii

Katolicki Uniwersytet Lubelski Jana Pawła II w Lublinie

\title{
ZACHOWANIA AUTOAGRESYWNE A OBRAZ WŁASNEGO CIAŁA U KOBIET Z ZABURZENIAMI ODŻYWIANIA SIE
}

\begin{abstract}
STRESZCZENIE
Celem artykułu jest przybliżenie zjawiska zaburzeń odżywiania się, obrazu własnego ciała i zachowań autoagresywnych, a także próba przedstawienia zależności między tymi zmiennymi u kobiet z zaburzeniami ożywiania się. Grupę badawczą (kliniczną) w projekcje stanowiło 25 kobiet ze zdiagnozowaną anoreksją lub bulimią, grupę kontrolną zaś - 30 kobiet zdrowych. Do badań wykorzystano Kwestionariusz Ja cielesnego (Skala J-C) Beaty Miruckiej oraz Inwentarz psychologicznego syndromu agresji (IPSA-II) Zbigniewa B. Gasia. Analiza uzyskanych wyników pokazuje, że kobiety z anoreksją i bulimią, w porównaniu do kobiet zdrowych, przejawiają większe tendencje autoagresywne. Ponadto w grupie badawczej niewłaściwy wizerunek ciała istotnie koreluje z nasileniem autoagresji. Uzyskane rezultaty przedyskutowano w świetle dotychczasowych wyników badań i teorii.
\end{abstract}

Słowa kluczowe: zachowania autoagresywne, obraz własnego ciała, zaburzenia odżywiania

\section{AUTOAGRESSIVE BEHAVIORS AND BODY IMAGE IN WOMEN WITH EATING DISORDERS}

\begin{abstract}
The purpose of this article is to present the phenomena of eating disorders, body image and autoaggressive behaviour and to attempt to present the relationship between these variables in women with eating disorders. The study group (clinical) in the project consisted of 25 women diagnosed with anorexia or bulimia, while the control group contained 30 healthy women. The research made use of the following methods: The Body Self Questionnaire (J-C Scale) by Beata Mirucka and the Inventory of the Psychological Aggression Syndrome (IPSA-II) by Zbigniew B. Gaś. The analysis of the results showed that women with anorexia and bulimia, had higher autoaggressive tendencies compared to healthy women. In addition, in the study group the disturbed body image significantly correlated with the increased autoaggressive behavior. The obtained results are discussed in the context of the existing research findings and theories.
\end{abstract}

Keywords: autoaggressive behavior, body image, eating disorders

\footnotetext{
${ }^{4}$ Adres do korespondencji: mioduchowska@o2.pl
} 


\section{WPROWADZENIE TEORETYCZNE}

Współczesny świat coraz częściej zachęca do zdrowego i ekologicznego stylu życia. Co więcej, stawia przed człowiekiem wiele wymagań: „bądź piękny!”, „weź się za siebie!”, „stosuj dietę!”. Nikt nie może pokazać słabości na zewnątrz, stąd często rodzi się ona wewnątrz osoby. Przegląd literatury (Brytek-Matera, 2008, 2011; Mirucka, 2005) na temat etiopatogenezy zaburzeń odżywiania się dowodzi, iż u podłoża tych zaburzeń znajduje się nieuświadomiony proces internalizacji ideału szczupłej figury, który jest dokonywany przez coraz młodsze kobiety. Skutkuje to m.in. niezadowoleniem z własnego ciała (Striegel-Moore, Franko, 2002), niską samooceną (Kołobo, Woynarowska, 2004) oraz zachowaniami autodestruktywnymi (Radziwiłłowicz, Raszka, 2008).

\section{ZABURZENIA ODŻYWIANIA SIE}

W ostatnich latach tematyka zaburzeń odżywiania się zyskała nieco na popularności, pomimo że samo zjawisko towarzyszy człowiekowi od zarania dziejów. Obecnie stanowi problem cywilizacyjny - dotyka on coraz więcej osób w coraz młodszym wieku, a ponadto częściej występuje w populacji żeńskiej niż męskiej. Najczęstsze formy takich zaburzeń to anoreksja i bulimia.

Międzynarodowa Klasyfikacja Chorób (ICD-10) opisuje anoreksję jako brak łaknienia lub awersję do pokarmu z „celową utratą wagi wywołaną i/albo podtrzymywaną przez pacjenta” (ICD-10, 2000, s. 151). Ryzyko wystąpienia anoreksji jest najwyższe między 14. a 18. rokiem życia. Statystycznie zaburzenie to występuje od 8 do 11 razy częściej u dziewcząt w okresie adolescencji oraz u młodych kobiet niż u chłopców i młodych mężczyzn. Anoreksja rozpoczyna się zwykle od odchudzania i objawia się niedożywieniem o różnym stopniu nasilenia. Dziewczynka, zwłaszcza początkowo, nie postrzega siebie jako osoby chorej, a spadek wagi ciała traktowany jest przez nią i otoczenie jako skutek odchudzającej diety. Chora konsekwentnie unika jedzenia, a z czasem całkowicie przestaje przyjmować pokarm, skupiając się na ćwiczeniach fizycznych i innych czynnościach przyspieszających utratę masy ciała (ICD-10, 2000; Józefik, Pilecki, 1999).

Wyróżnia się dwie kliniczne postaci anoreksji: restrykcyjną (ograniczającą) i bulimiczną (objadająco-przeczyszczającą / żarłoczno-wydalającą). W postaci restrykcyjnej osoba ogranicza spożywanie pokarmów do bardzo niewielkich ilości i czasem nieregularnie stosuje środki przeczyszczające. Z kolei w postaci bulimicznej osoba również ogranicza przyjmowanie pokarmów, a dodatkowo regularnie miewa okresy przejadania się i/lub wymiotowania oraz nadużywa leków moczopędnych i/lub przeczyszczających (Kendall, 2004; Kozak, Kozak, 2003).

Drugim co do częstości występowania zaburzeniem odżywiania się jest bulimia, która charakteryzuje się „okresowymi napadami obżarstwa i nadmierną koncentracją na kontroli masy ciała" (ICD-10, 2000, s. 152). Podczas tzw. epizodu objadania się osoby spożywają olbrzymie ilości jedzenia, doświadczając przy tym całkowitego braku kontroli nad przebiegiem sytuacji. Po ataku czują chwilową ulgę wynikającą z obniżenia się początkowego napięcia. Jednak szybko przeradza się ona w poczucie winy związane $\mathrm{z}$ frustrującą świadomością utraty panowania nad sobą. W konsekwencji zmusza to do zachowań kompensacyjnych w celu przeciwdziałania tuczącym skutkom spożytego pokarmu i oczyszczenia się, zazwyczaj przez prowokowanie wymiotów. Podobnie jak w wypadku anoreksji, na bulimię chorują przeważnie dziewczynki i kobiety, jednak pierwsze objawy 
pojawiają się w trochę późniejszym wieku. Zaburzenie zwykle występuje u tych kobiet, które próbując kontrolować wagę ciała, stosowały wcześniej różne metody odchudzające. Niektóre też, przed wystąpieniem typowej bulimii, objadały się, po czym przechodziły na rygorystyczną dietę. Zdarza się, że bulimia przeradza się w anoreksję lub też anoreksja przechodzi w bulimię. Wzrasta wtedy masa ciała i powraca miesiączkowanie, ale zaczyna się też uciążliwa sekwencja przejadania się i prowokowania wymiotów (Bilikiewicz, 2003; Brytek-Matera, 2008, 2011; Wciórka, 2008).

Amerykańskie Towarzystwo Psychiatryczne w swojej klasyfikacji zaburzeń psychicznych DSM-IV-TR wyodrębnia bulimię przeczyszczającą (purging type) oraz nieprzeczyszczającą (non-purging type) (Wciórka, 2008). W typie przeczyszczającym osoba, po każdym epizodzie objadania się, nadużywa środków przeczyszczających i odwadniających, prowokuje wymioty lub stosuje lewatywy. W typie nieprzeczyszczającym, po objadaniu się, osoba stosuje różne zachowania kompensacyjne, tj. głodówki, ćwiczenia fizyczne, nieregularne wymioty (Bilikiewicz, 2003; Brytek-Matera, 2008; Józefik, Pilecki, 1999; Rajewski, 2004; Wciórka, 2008).

\section{OBRAZ WŁASNEGO CIAŁA}

Zaburzenia odżywiania się, tj. anoreksja i bulimia, są mocno powiązane z niewłaściwym obrazem ciała. Definiując zjawisko obrazu własnego ciała, można powiedzieć, iż jest to kreowany w naszym umyśle wizerunek, przez który ciało objawia się nam samym (Schilder, 1935, za: Mirucka, 2003). Kreowanie to zachodzi pod wpływem nowych doświadczeń oraz napływających informacji (z zewnątrz i z wewnątrz), dzięki czemu obraz ciała może się zmieniać w ciągu całego życia (Kowalik, 2003; Mirucka, 2003). Z kolei definicja Slade’a (1994) ujmuje dodatkowo postawy wobec własnego ciała. Mówi ona, iż „obraz, który mamy w swoim umyśle, dotyczy rozmiarów, kształtu i formy naszego ciała oraz naszych uczuć skierowanych do właściwości i składowych części naszego ciała” (za: Mirucka, 2003, s. 31). Subiektywne doświadczanie ciała jako pewnej spójnej i trwałej własności pozwala wyodrębnić się z JA osoby tzw. Ja-cielesnego. To z kolei wzbogaca relację „podmiot - ciało” o nową relację "podmiot (JA) - moje doświadczenie mnie cielesnego” (Mirucka, 2003, s. 32). Ja-cielesne jest zatem sumą tego, co stanowi materialne źródło naszych wrażeń napływających z wnętrza ciała, wizji na jego temat, a także przeżyć połączonych z doświadczanymi wrażeniami cielesnymi (Kowalik, 2003). Z kolei stanowisko Miruckiej $(2003,2005)$ zakłada, że Ja-cielesne w aspekcie podmiotowym jest źródłem „doświadczania siebie w swoim ciele wraz ze swoją płciowością" (s. 32). Jednocześnie w aspekcie przedmiotowym stanowi ono percepcyjny wizerunek własnego ciała razem ze świadomymi i nieświadomymi doświadczeniami cielesnymi (Brytek-Matera, 2008, 2011; Mirucka, 2003; Sakson-Obada, 2009).

Ja-cielesne, podobnie jak i inne elementy systemu JA, zaczyna się kształtować już od najwcześniejszych lat i rozwija się przez całe życie człowieka. Najbardziej widoczne jest to wtedy, kiedy w ciele i jego doświadczaniu zachodzą intensywne przemiany, jak np. podczas osiągania dojrzałości płciowej (Mirucka, 2005; Sakson-Obada, 2009; Sikorska, 2008). Kiedy Ja-cielesne razem $\mathrm{z}$ innymi podsystemami JA stwarza zintegrowany system, mówi się o osobowości funkcjonującej prawidłowo. W takiej osobowości Ja-cielesne wybija się na pierwszy plan jedynie w wyjątkowych sytuacjach, w których cielesność odgrywa istotną rolę (np. w doświadczeniu bólu). Jednak permanentne wyodrębnienie się Ja-cielesnego z JA może już świadczyć o pewnej patologii. Przyczyną takiego stanu jest zwykle brak akceptacji 
dla własnej cielesności, czasem aż do jej zanegowania i odrzucenia (Brytek-Matera, 2008, 2011; Mirucka, 2003, 2005).

Niewłaściwy obraz własnego ciała współistnieje z zaburzeniami odżywiania się. Badania przeprowadzone w Polsce pokazały, że młodzież (11-15 lat) postrzega nieadekwatnie swoją masę ciała w porównaniu do stanu faktycznego. Prawie co druga dziewczynka i co czwarty chłopiec uważają, że mają problem z nadwagą, pomimo że ich wskaźniki BMI mieszczą się w normie (Kołobo, Woynarowska, 2004). Według innych badań prawie $60 \%$ dziewcząt odchudzało się w przeszłości, 11\% zaś cały czas przestrzega diety odchudzającej, a tylko $29 \%$ badanych nie czuje potrzeby odchudzania się. Okazuje się, że ponad połowa badanych nastolatków przejawia niezadowolenie ze swojego fizycznego wyglądu, 36\% natomiast ewidentnie nie akceptuje własnej figury. Aż 72\% badanych dziewcząt prezentuje zachowania charakterystyczne dla zaburzeń odżywiania się, tj. konsumowanie w ukryciu, odczuwanie wstydu i nienawiści do siebie z powodu wzmożonego apetytu i przejadania się, niemożność zaprzestania jedzenia, a także potrzebę jedzenia w sytuacjach stresujących. Udowodniono ponadto, iż nastoletnie dziewczęta, które stosują nieprawidłową dietę, są aż 7-krotnie częściej narażone na zaburzenia odżywiania się aniżeli dziewczęta, które odżywiają się w sposób prawidłowy (Lwow, Dunajska, Milewicz, 2007). Inne badania dowiodły, że 33\% nastolatków próbuje się odchudzać przez stosowanie różnych metod odchudzających, w tym także drastycznych. Ponad jedna czwarta badanych wyraża chęć obniżenia masy swojego ciała, w tym połowa deklaruje wzmożone spożywanie pokarmów, $40 \%$ objawia lęk przed otyłością, 28\% przejawia jadłowstręt, a prawie co dziesiąta osoba wywołuje wymioty (Wojtyła, Biliński, Bojar, Wojtyła, 2011).

W przypadku anoreksji możliwość wyzdrowienia odnotowuje się u 40-70\% wszystkich pacjentów. Częściowa poprawa stanu zdrowia jest odnotowywana w przedziale od kilku aż do $40 \%$. Przewlekły obraz choroby występuje u około $20 \%$ pacjentów. Wśród chorych umiera aż 10-20\%, a najczęstszymi przyczynami są niedożywienie i samobójstwo. Jeśli natomiast chodzi o bulimię, poprawa stanu zdrowia mieści się w granicach od 30 do $60 \%$. Brak poprawy zachodzi u 5-25\% pacjentów (Wojtyła i in., 2011).

Jak podają powyższe statystyki, zaburzenia odżywiania się, tj. anoreksja i bulimia, charakteryzują się nieadekwatnym spostrzeganiem własnego ciała oraz nadmierną koncentracją na nim. W związku z tym - nieodpowiednim traktowaniu siebie przez typowe, często destrukcyjne, sposoby funkcjonowania.

\section{ZACHOWANIA AUTOAGRESYWNE}

Pojęcie autoagresji obejmuje szereg destrukcyjnych, skierowanych do siebie działań, które są podejmowane w sposób dobrowolny oraz intencjonalny. Doprowadzają one do uszkodzenia własnego ciała, co może zagrażać zdrowiu lub też życiu danej osoby (Tate, Baroff, 1966, za: Babiker, Arnold, 2003). Najczęstszymi formami takich zachowań są: cięcie skóry różnych części ciała, poparzenia wodą, substancjami chemicznymi i ogniem, obijanie się o ściany albo wymierzanie sobie ciosów. Niektóre osoby uszkadzają się każdorazowo w inny sposób, co uzależnione jest od aktualnego stanu emocjonalnego bądź też dostępnych narzędzi (Chojnacka, Karczewski, 2003; Eckhardt, 1998).

Literatura przedmiotu podaje, że autoagresja jest częstszym zjawiskiem wśród kobiet niż wśród mężczyzn. W społeczeństwie przyjęło się bowiem, iż kobietom nie wypada jawnie wyrażać negatywnych uczuć. Takie pohamowywanie agresji może doprowadzić do 
zwiększenia się frustracji, a w ostateczności do skierowania się przeciwko sobie (Babiker, Arnold, 2003; Eckhardt, 1998; Wycisk, 2003). Ponadto samouszkodzenia dokonywane przez kobiety znacznie różnią się od samouszkodzeń u mężczyzn. Jedne z teorii wyjaśniają takie zjawisko potencjalnym znaczeniem międzypłciowych różnic anatomicznych (np. Cross, 1993). Inne teorie podkreślają znaczenie procesu socjalizacyjnego, który kładzie nacisk na określone role dziewczynek i kobiet oraz chłopców i mężczyzn (np. Burstow, 1992). Okazuje się, że u kobiet zachowania autoagresywne o wiele częściej koncentrują się bezpośrednio na ciele (Wycisk, 2003). Badania nt. anoreksji pokazują, że u chorych kobiet występuje zaburzony schemat własnego ciała (Lask, Bryant-Waugh, 1992, za: Wolska, 1999). Co więcej, nawet kobiety zdrowe przejawiają nieadekwatnie zawyżoną ocenę wymiarów swojego ciała (Striegel-Moore, Franko, 2002). W literaturze często się podkreśla, iż kobiety są zdecydowanie bardziej niezadowolone ze swojego wyglądu aniżeli mężczyźni (Bem, 2000), stąd też u kobiet może następować wzmożona kontrola wagi ciała oraz poddawanie go licznym zabiegom upiększającym.

Przyczyny zachowań autoagresywnych mogą być związane m.in. z nieprawidłowym rozwojem JA osoby, a zwłaszcza z rozwojem Ja-cielesnego. Jak wyjaśnia podejście psychodynamiczne, nieprawidłowo ukształtowane Ja-cielesne stanowi swoiste źródło przeszkody w doświadczeniu własnego ciała oraz umysłu jako zjednoczonej całości (Krueger, 2002; Zerbe, 1993, za: Mirucka, 2003, s. 35). W związku z tym kobiety postrzegają swoje ciało i siebie jako całkowicie odrębne elementy, a występujące tu zjawisko fragmentaryzacji objawia się m.in. wstydem, dezintegracyjnym lękiem, złością, hipochondrycznością czy seksualizacją relacji międzyludzkich (Mirucka, 2003, 2005).

\section{ZWIĄZEK AUTOAGRESJI, OBRAZU CIAŁA I ZABURZEŃ ODŻYWIANIA SIĘ}

W literaturze przedmiotu można się spotkać ze stanowiskiem, które w obrazie zaburzeń odżywiania się uwzględnia problem autoagresji. Anoreksja i bulimia często określane są jako zachowania autodestruktywne (autoagresywne), które polegają na dążeniu do samounicestwienia siebie. W samym przebiegu zaburzeń odży wiania się można zaobserwować różne tendencje autoagresywne jako przejaw niewłaściwego sposobu spostrzegania ciała.

$\mathrm{U}$ kobiet autoagresywnych, wraz $\mathrm{z}$ rozwojem choroby albo nawet w momencie pojawienia się jej, dochodzi do zaburzeń odżywiania się i odwrotnie - kobiety z zaburzeniami odżywiania się często są jednocześnie autoagresywne. Sansone i Levitt (2002) zaobserwowali, że wielu pacjentów z zaburzeniami odżywiania się przejawiało różne zachowania autodestrukcyjne w przeszłości i teraźniejszości. Okazuje się, że autodestrukcyjne zachowania zdarzają się równie często w bulimii, jak i w anoreksji (u 37\% osób badanych; Favaro, Santonastaso, 1997). Inne badania wskazują na przewagę tych zachowań w anoreksji (41,7\%) w stosunku do bulimii (34,3\%) (Paul, Schroeder, Dahme, Nutzinger, 2002). Istnieje również stanowisko, że tendencje autoagresywne częściej występują u osób uzależnionych od środków przeczyszczających, z czym mamy do czynienia w bulimii i anoreksji typu bulimicznego. Niemniej jednak można wnioskować, iż zaburzenia odżywiania się stanowią chroniczny przejaw autodestruktywności (Radziwiłłowicz, Reszka, 2008; Sakson-Obada, 2009). Głodzenie się, epizody impulsywnego objadania i przeczyszczania oraz samouszkodzenia „stanowią triadę wzajemnie powiązanych syndromów autodestruktywności, które są też skojarzone z traumą i również dlatego trudne do wyleczenia” (Radziwiłłowicz, Reszka, 2008, s. 145-146). W badaniach Radziwiłłowicz 
i Reszki (2008) nt. autoagresywnych zachowań u kobiet z anoreksją okazało się, że chore nie akceptują swojego ciała, nie szanują go, a nawet zaniżają własną samoocenę. Ponadto, dla zwrócenia uwagi otoczenia, podejmują różne formy autodestrukcji (autoagresji) pośredniej i bezpośredniej. Jednak zachowania te, a zwłaszcza próby samobójcze, nie mają na celu odebrania sobie życia. W innych badaniach (Ruuska, Kaltiala-Heino, Rantanen, Koivisto, 2005) okazało się, że ponad połowa przebadanych pacjentek $\mathrm{z}$ anoreksją i bulimią miała samobójcze myśli albo rozpatrywała odebranie sobie życia. Jeszcze inne pokazują, że ryzyko myśli i prób samobójczych jest większe w bulimii i typie przeczyszczającym anoreksji (62\% i 10\%) niż w samej anoreksji (54\% i 9\%) (Paul i in., 2002). Może to wynikać z faktu, że w bulimii częściej występują objawy depresyjne oraz zachowania obsesyjne i impulsywne, w anoreksji zaś częściej panuje przekonanie o własnej doskonałej kontroli wewnętrznej (Radziwiłłowicz, Reszka, 2008; Sakson-Obada, 2009).

Na podstawie przytoczonych badań i teorii można stwierdzić, że zachowania autoagresywne mogą byś środkiem, przez który osoba potwierdza i wzmacnia niedowartościowane aspekty swojego JA, a nawet zaspokaja jego potrzeby. Obok bezpośredniej autoagresji (samookaleczenia i próby samobójcze) mogą się pojawiać formy bardziej chroniczne, takie jak np. zaburzenia odżywiania się. Kobiety z anoreksją czy bulimią podejmują często zachowania autodestrukcyjne. Odmowa przyjmowania jedzenia albo niekontrolowane jedzenie są taką właśnie formą systematycznego samoniszczenia. Kobiety te zaprzeczają potrzebie jedzenia, kompensacyjnym zachowaniom, a nawet swemu niezdrowemu wyglądowi. Ponadto zaprzeczają często własnej chorobie i wiążącym się z nią problemom, a im dłuższy jest czas trwania tych zaburzeń, tym większe ryzyko myśli samobójczych i podjęcia samobójczej próby (Babiker, Arnold, 2003; Brytek-Matera, 2008; Radziwiłłowicz, Reszka, 2008; Sakson-Obada, 2009).

W związku z powyższym interesujące wydaje się zbadanie związku obrazu własnego ciała i tendencji autoagresywnych u kobiet z zaburzeniami odżywiania się. Stanowi to cel niniejszego projektu badawczego, który przedstawia dwie hipotezy badawcze. Pierwsza hipoteza zakłada, że kobiety z zaburzeniami odżywiania się różnią się od kobiet zdrowych ze względu na zachowania autoagresywne, które są u nich bardziej nasilone. Hipoteza ta jest możliwa, ponieważ w literaturze przedmiotu zaburzenia odżywiania się są zestawiane z innymi zachowaniami szkodliwymi dla ciała. Ross i McKay (1979, za: Babiker, Arnold, 2003, s. 24) zaliczają ponadto te zaburzenia do autoagresji pośredniej, gdzie związek między zachowaniem a jego konsekwencją jest odległy i niejednoznaczny. W niniejszej pracy zostały również przytoczone inne stanowiska, które traktują anoreksję i bulimię jako zachowania autodestrukcyjne, polegające na kierowaniu agresji na własne ciało, czego konsekwencją jest dążenie do samounicestwienia.

Z kolei hipoteza druga zakłada, iż u kobiet z zaburzeniami odżywiania się zachodzi dodatnia zależność między nieadaptacyjnym obrazem własnego ciała a tendencjami autoagresywnymi. Hipoteza ta może być prawdopodobna, jak bowiem podaje literatura przedmiotu, podstawowym składnikiem psychopatologicznego obrazu anoreksji i bulimii oraz tendencji autoagresywnych jest zaburzony wizerunek własnego ciała. Ponadto liczne badania przytoczone w niniejszym artykule pokazują, że nieprawidłowy obraz ciała skutkuje wrogim i agresywnym nastawieniem do siebie. 


\section{METODA}

Do pomiaru badanych zmiennych wykorzystano dwie metody kwestionariuszowe: Kwestionariusz Ja cielesnego (Skala J-C) Beaty Miruckiej oraz Inwentarz psychologicznego syndromu agresji (IPSA-II) Zbigniewa B. Gasia.

Kwestionariusz Ja cielesnego (Skala J-C) służy do oceny obrazu własnego ciała u kobiet od 13. roku życia. Składa się z 49 pozycji testowych (w tym ośmiu niediagnostycznych), przyporządkowanych do czterech wymiarów Ja-cielesnego: skala $\mathrm{M}$ (przeżywanie intymności z osobami płci przeciwnej), skala A (akceptacja cielesności), skala E (stosunek do jedzenia i wagi ciała), skala $\mathrm{K}$ (eksponowanie kobiecości). Odpowiedzi są udzielane na 7-stopniowej skali, przez odpowiednie odniesienie się do każdego twierdzenia. Wyniki niskie wskazują na słabe Ja-cielesne i zaburzony obraz własnego ciała. Wyniki wysokie świadczą natomiast o silnym i właściwie rozwiniętym Ja-cielesnym, z prawidłowym obrazem własnego ciała. Skala J-C ma dobrą trafność diagnostyczną (analiza wariancji Oneway ANOVA $F=108,47$ dla całej Skali J-C) i wysoką rzetelność (współczynnik zgodności wewnętrznej alfa Cronbacha dla całej Skali J-C wynosi 0,93) (Mirucka, 2003, 2005).

Druga metoda, Inwentarz psychologicznego syndromu agresji (IPSA-II), została opracowana przez Gasia, jako zmodyfikowana wersja Inwentarza psychologicznego syndromu agresji (IPSA) z 1980 roku. Służy do pomiaru nasilenia agresji oraz jej jakościowej analizy u osób dorosłych - kobiet i mężczyzn. IPSA-II zbudowana jest z 56 twierdzeń pogrupowanych na 11 czynników: skłonność do działań odwetowych, tendencje autodestrukcyjne, zaburzenia kontroli agresji, agresja przemieszczona, nieuświadomione tendencje agresywne, agresja pośrednia, agresja instrumentalna, wrogość wobec siebie, agresja fizyczna wobec otoczenia, wrogość wobec otoczenia, agresja reaktywna. Zadaniem osoby badanej jest ustosunkowanie się do każdego z twierdzeń przez zaznaczenie jednej z trzech możliwych odpowiedzi: prawda, ?, fałsz. Im wyższy wynik, tym większe nasilenie zachowań agresywnych i autoagresywnych. IPSA-II ma wysoką trafność teoretyczną (współczynnik korelacji wyniku ogólnego między IPSA a IPSA-II wynosi dla kobiet 0,98, a dla mężczyzn 0,97) i wysoką rzetelność (wskaźnik estymacji stabilności bezwzględnej wyniku ogólnego sprawdzony przez dwukrotne zbadanie tej samej grupy osób wynosi dla kobiet 0,86, a dla mężczyzn 0,84) (Gaś, 1987a, 1987b).

\section{OSOBY BADANE}

Postawione hipotezy zostały zweryfikowane w oparciu o wyniki badań przeprowadzonych na 55 kobietach w wieku od 15 do 30 lat $(M=21,9)$, z czego 25 kobiet tworzyło grupe kliniczną ( $M=20,8$ lat), a 30 - grupę kontrolną ( $M=22,9$ lat). Różnica w liczebności obu grup wynika z faktu, iż dostęp do kobiet z zaburzeniami odżywiania się był utrudniony procedurami szpitalnymi, liczebnością pacjentek przebywających na oddziałach i uzyskaniem od nich zgody na udział w badaniach. W związku z tym do grupy klinicznej włączono również kobiety poniżej 16. roku życia.

W grupie klinicznej znalazły się kobiety ze zdiagnozowanymi zaburzeniami odżywiania się: anoreksją lub bulimią. Kryterium doboru do grupy stanowiła klasyfikacja diagnostyczna ICD-10, a także płeć. Niniejsze badania przeprowadzono wśród kobiet ze względu na częstszą w tej populacji zachorowalność na zaburzenia odżywiania się niż w populacji męskiej. Ponadto Skala J-C przeznaczona jest tylko do badania kobiet. 
Badania w grupie klinicznej zostały przeprowadzone indywidualnie i anonimowo w Szpitalu Neuropsychiatrycznym im. prof. M. Kaczyńskiego w Lublinie na oddziale psychiatrycznym oraz w Klinice Psychiatrii Uniwersytetu Medycznego w Lublinie na oddziale nerwicowym w okresie od kwietnia 2009 do maja 2010 roku. Grupa była wewnętrznie zróżnicowana pod względem rodzaju zaburzeń odżywiania się: 11 kobiet $z$ anoreksją (44\%), 11 z bulimią (44\%) oraz 3 z mieszanym zaburzeniem odżywiania się (12\%). Termin „mieszane zaburzenie" opisuje pacjentki, w stosunku do których lekarze nie potrafili przypisać konkretnej jednostki chorobowej wg ICD-10, ponieważ przejawiały one zachowania charakterystyczne zarówno dla anoreksji, jak i bulimii. W związku z powyższym, jak również w związku z małą liczebnością tej grupy, pacjentki z zaburzeniem mieszanym nie zostały uwzględnione w statystycznych badaniach korelacyjnych.

Grupę kontrolną stanowiły studentki i absolwentki lubelskich uczelni wyższych (KUL, UMCS, UP, UM). Kryterium doboru była płeć żeńska, wiek zbliżony do grupy klinicznej i diagnoza braku zaburzeń odżywiania się (wg ICD-10).

Trzeba zaznaczyć, iż niniejszy artykuł jest zgodny ze standardami etycznymi - zarówno pod względem postępowania wobec osób badanych, jak i wykorzystania narzędzi oraz procedur autorstwa innych badaczy.

\section{WYNIKI}

Dla sprawdzenia różnic, jakie zachodzą między kobietami z zaburzeniami odżywiania się i kobietami zdrowymi pod względem wizerunku własnego ciała, posłużono się Skala Ja cielesnego (Skala J-C). Wyniki obu grup zaprezentowano w tabeli 1.

Tabela 1

Średnie wyniki i różnice między grupami uzyskane w Skali J-C

\begin{tabular}{|c|c|c|c|c|c|c|c|c|c|c|}
\hline \multirow{2}{*}{ Skala J-C } & \multicolumn{4}{|c|}{ Gr. kliniczna $(N=25)$} & \multicolumn{4}{|c|}{ Gr. kontrolna $(N=30)$} & \multicolumn{2}{|c|}{$\begin{array}{l}\text { Test } t \\
\text { dla grup } \\
\text { niezależnych }\end{array}$} \\
\hline & $M$ & $S D$ & $\begin{array}{l}\text { Kołmo } \\
\text { Smirn } \\
z \text { K-S }\end{array}$ & $\begin{array}{l}\text { sorow- } \\
p<\end{array}$ & $M$ & $S D$ & $\begin{array}{l}\text { Kołmo } \\
\text { Smirn } \\
z \text { K-S }\end{array}$ & $\begin{array}{l}\text { orow- } \\
\text { N } \\
p<\end{array}$ & $t$ & $p<$ \\
\hline Wynik ogólny & 86,16 & 44,35 & 0,94 & 0,35 & 183,57 & 26,32 & 0,68 & 0,74 & 9,66 & 0,001 \\
\hline $\begin{array}{l}\text { Przeżywanie } \\
\text { intymności } \\
\text { z osobami płci } \\
\text { przeciwnej }\end{array}$ & 27,60 & 17,42 & 0,75 & 0,75 & 56,07 & 9,80 & 0,79 & 0,56 & 7,27 & 0,001 \\
\hline $\begin{array}{l}\text { Akceptacja } \\
\text { cielesności }\end{array}$ & 25,24 & 16,76 & 0,66 & 0,78 & 59,63 & 10,31 & 0,68 & 0,75 & 8,95 & 0,001 \\
\hline $\begin{array}{l}\text { Stosunek } \\
\text { do jedzenia } \\
\text { i wagi ciała }\end{array}$ & 19,48 & 12,31 & 1,06 & 0,21 & 44,53 & 10,00 & 0,58 & 0,89 & 8,33 & 0,001 \\
\hline $\begin{array}{l}\text { Eksponowanie } \\
\text { kobiecości }\end{array}$ & 13,84 & 7,55 & 0,90 & 0,40 & 23,33 & 6,71 & 0,66 & 0,77 & 4,94 & 0,001 \\
\hline
\end{tabular}


Powyższe statystyki opisowe ( $M$ i $S D$ ) oraz wyniki testu Kołmogorowa-Smirnowa spełniają założenie o normalności rozkładu, w związku z czym zastosowano parametryczny test $t$ dla grup niezależnych. Uzyskane dane wskazują na istotne różnice w wyniku ogólnym oraz we wszystkich podskalach między badanymi grupami. Średnie wyników $(M)$ ogólnych oraz w podskalach: przeżywanie intymności w relacji z osobami płci przeciwnej, akceptacja cielesności, stosunek do jedzenia i wagi ciała oraz eksponowanie kobiecości są zdecydowanie niższe w grupie klinicznej niż w grupie kontrolnej.

Tak zaprezentowane dane pokazują, że kobiety z zaburzeniami odżywiania się różnią się od kobiet zdrowych pod względem obrazu własnego ciała. Nie akceptują one swojej cielesności, w sytuacjach intymnych z mężczyznami doświadczają lęku i niepokoju, co może dodatkowo hamować eksponowanie kobiecości. Ich postawa względem czynności związanych z jedzeniem i utrzymaniem określonej wagi ciała jest nieadekwatna.

W celu sprawdzenia różnic zachodzących między badanymi grupami pod względem zachowań autoagresywnych posłużono się metodą IPSA-II. Wyniki prezentuje tabela 2.

Tabela 2

Średnie wyniki i różnice między grupami uzyskane w IPSA-II

\begin{tabular}{|c|c|c|c|c|c|c|c|c|c|c|}
\hline \multirow[b]{2}{*}{ IPSA-II } & \multicolumn{4}{|c|}{ Gr. kliniczna $(N=25)$} & \multicolumn{4}{|c|}{ Gr. kontrolna $(N=30)$} & \multicolumn{2}{|c|}{$\begin{array}{l}\text { Test } t \text { dla grup } \\
\text { niezależnych }\end{array}$} \\
\hline & $M$ & $S D$ & \multicolumn{2}{|c|}{$\begin{array}{l}\text { Kołmogorow- } \\
\text { Smirnow }\end{array}$} & $M$ & $S D$ & \multicolumn{2}{|c|}{$\begin{array}{l}\text { Kołmogorow- } \\
\text { Smirnow }\end{array}$} & $t$ & $p<$ \\
\hline Wynik ogólny & 31,80 & 17,19 & 0,45 & 0,99 & 15,30 & 10,63 & 0,98 & 0,30 & 4,18 & 0,001 \\
\hline $\begin{array}{l}\text { Skłonność } \\
\text { do działań } \\
\text { odwetowych }\end{array}$ & 5,76 & 5,40 & 1,19 & 0,12 & 3,80 & 4,69 & 1,15 & 0,15 & 1,44 & n.i. \\
\hline $\begin{array}{l}\text { Zaburzenia } \\
\text { kontroli agresji }\end{array}$ & 5,88 & 4,19 & 0,77 & 0,60 & 3,90 & 2,93 & 0,66 & 0,78 & 1,99 & 0,06 \\
\hline $\begin{array}{l}\text { Agresja } \\
\text { przemieszczona }\end{array}$ & 4,20 & 4,11 & 0,92 & 0,37 & 1,53 & 1,74 & 1,34 & 0,55 & 3,03 & 0,005 \\
\hline $\begin{array}{l}\text { Nieuświadomione } \\
\text { tendencje } \\
\text { agresywne }\end{array}$ & 4,04 & 2,91 & 0,79 & 0,56 & 4,20 & 3,42 & 0,95 & 0,33 & 0,19 & n.i. \\
\hline \multirow[t]{3}{*}{ Agresja reaktywna } & 6,32 & 3,46 & 1,08 & 0,19 & 4,90 & 2,34 & 0,81 & 0,53 & 1,74 & 0,1 \\
\hline & & & & & & & & \multicolumn{3}{|c|}{ U Manna-Whitneya } \\
\hline & & & & & & & & & $U$ & $p<$ \\
\hline $\begin{array}{l}\text { Tendencje } \\
\text { autodestrukcyjne }\end{array}$ & 7,48 & 4,97 & 1,10 & 0,18 & 1,17 & 1,60 & 1,65 & 0,009 & 117 & 0,001 \\
\hline Agresja pośrednia & 3,08 & 2,31 & 0,80 & 0,54 & 1,77 & 1,89 & 1,56 & 0,016 & 240 & 0,018 \\
\hline $\begin{array}{l}\text { Agresja } \\
\text { instrumentalna }\end{array}$ & 4,04 & 3,48 & 0,92 & 0,36 & 0,97 & 1,25 & 1,91 & 0,001 & 169 & 0,001 \\
\hline $\begin{array}{l}\text { Wrogość wobec } \\
\text { siebie }\end{array}$ & 4,48 & 2,47 & 0,61 & 0,85 & 0,63 & 1,13 & 2,26 & 0,001 & 57 & 0,001 \\
\hline $\begin{array}{l}\text { Agresja fizyczna } \\
\text { wobec otoczenia }\end{array}$ & 1,20 & 1,94 & 1,66 & 0,01 & 0,53 & 1,28 & 2,71 & 0,001 & 293,5 & 0,078 \\
\hline $\begin{array}{l}\text { Wrogość wobec } \\
\text { otoczenia }\end{array}$ & 4,64 & 2,71 & 1,03 & 0,24 & 1,53 & 1,66 & 1,40 & 0,04 & 123,5 & 0,001 \\
\hline
\end{tabular}


Powyższe statystyki opisowe ( $M$ i $S D$ ) oraz wyniki testu Kołmogorowa-Smirnowa spełniają założenie o normalności rozkładu dla wyniku ogólnego oraz dla takich czynników jak: skłonność do działań odwetowych, zaburzenia kontroli agresji, agresja przemieszczona, nieuświadomione tendencje agresywne i agresja reaktywna. W związku $\mathrm{z}$ tym zastosowano tu parametryczny test $t$ dla grup niezależnych. Z kolei wyniki testu Kołmogorowa-Smirnowa nie spełniają założenia o normalności rozkładu dla tendencji autodestrukcyjnych, agresji pośredniej, agresji instrumentalnej, wrogości wobec siebie, agresji fizycznej wobec otoczenia i wrogości wobec otoczenia. W związku z tym zastosowano tu test nieparametryczny $U$ Manna-Whitneya. Zaprezentowane wyniki pokazują istotną różnicę między badanymi grupami pod względem wyniku ogólnego w IPSA-II. Ponadto istotne różnice na takim samym poziomie występują w następujących podskalach: tendencje autodestrukcyjne, agresja instrumentalna, wrogość wobec siebie i wrogość wobec otoczenia. Różnica istotna na poziomie $p<0,005$ występuje natomiast w podskali agresja przemieszczona, a na poziomie $p<0,05 \mathrm{w}$ podskalach agresja pośrednia i agresja fizyczna wobec otoczenia. Współczynnik $t$ w wyniku ogólnym oraz współczynniki $t$ i $U$ w tych podskalach mają charakter dodatni. Średnia $(M)$ dla wyniku ogólnego i wymienionych podskal jest zdecydowanie wyższa w grupie klinicznej aniżeli w kontrolnej.

Takie dane świadczą o tym, że kobiety z zaburzeniami odżywiania się różnią się od kobiet zdrowych ze względu na ogólne nasilenie agresji. Ponadto częściej przejawiają zachowania autoagresywne, agresję przemieszczoną, rozładowywaną na przedmiotach, oraz instrumentalną, służącą określonym celom. Atakują innych pośrednio przez ośmieszanie, krytykowanie czy plotkowanie. Są też wrogo nastawione wobec siebie i otoczenia.

Następnie sprawdzono, jakie korelacje zachodzą między zmiennymi Skali J-C oraz IPSA-II w grupie kobiet z zaburzeniami odżywiania się. Uzyskane wyniki przedstawia tabela 3.

Analiza korelacji pokazuje, że uzyskane istotne współzależności między wynikami ogólnymi i podskalami obu metod mają charakter ujemny. U kobiet z zaburzeniami odżywiania się wynik ogólny Skali J-C wiąże się ponadto wysoko z wrogością wobec siebie i tendencjami autodestrukcyjnymi, umiarkowanie zaś z agresją instrumentalną, wrogością wobec otoczenia, wynikiem ogólnym IPSA-II i agresją pośrednią. Następny czynnik, przeżywanie intymności z osobami płci przeciwnej, koreluje umiarkowanie $z$ wrogością wobec siebie, agresją instrumentalną, wrogością wobec otoczenia, tendencjami autodestrukcyjnymi, wynikiem ogólnym i agresją pośrednią. Czynnik akceptacja cielesności koreluje umiarkowanie z wrogością wobec siebie, tendencjami autodestrukcyjnymi, agresją instrumentalną oraz z wynikiem ogólnym IPSA-II. Czynnik stosunek do jedzenia i wagi ciała koreluje umiarkowanie z agresją instrumentalną, wynikiem ogólnym IPSA-II, agresją pośrednią, wrogością wobec siebie, tendencjami autodestrukcyjnymi, zaburzeniami kontroli agresji i agresją przemieszczoną. Czynnik eksponowanie kobiecości koreluje natomiast na poziomie umiarkowanym z wrogością wobec siebie i tendencjami autodestrukcyjnymi.

Dla porównania, poniższa tabela prezentuje korelacje badanych zmiennych dla grupy kontrolnej (tabela 4). 
Tabela 3

Korelacje (r Pearsona) między zmiennymi Skali J-C oraz IPSA-II dla grupy klinicznej

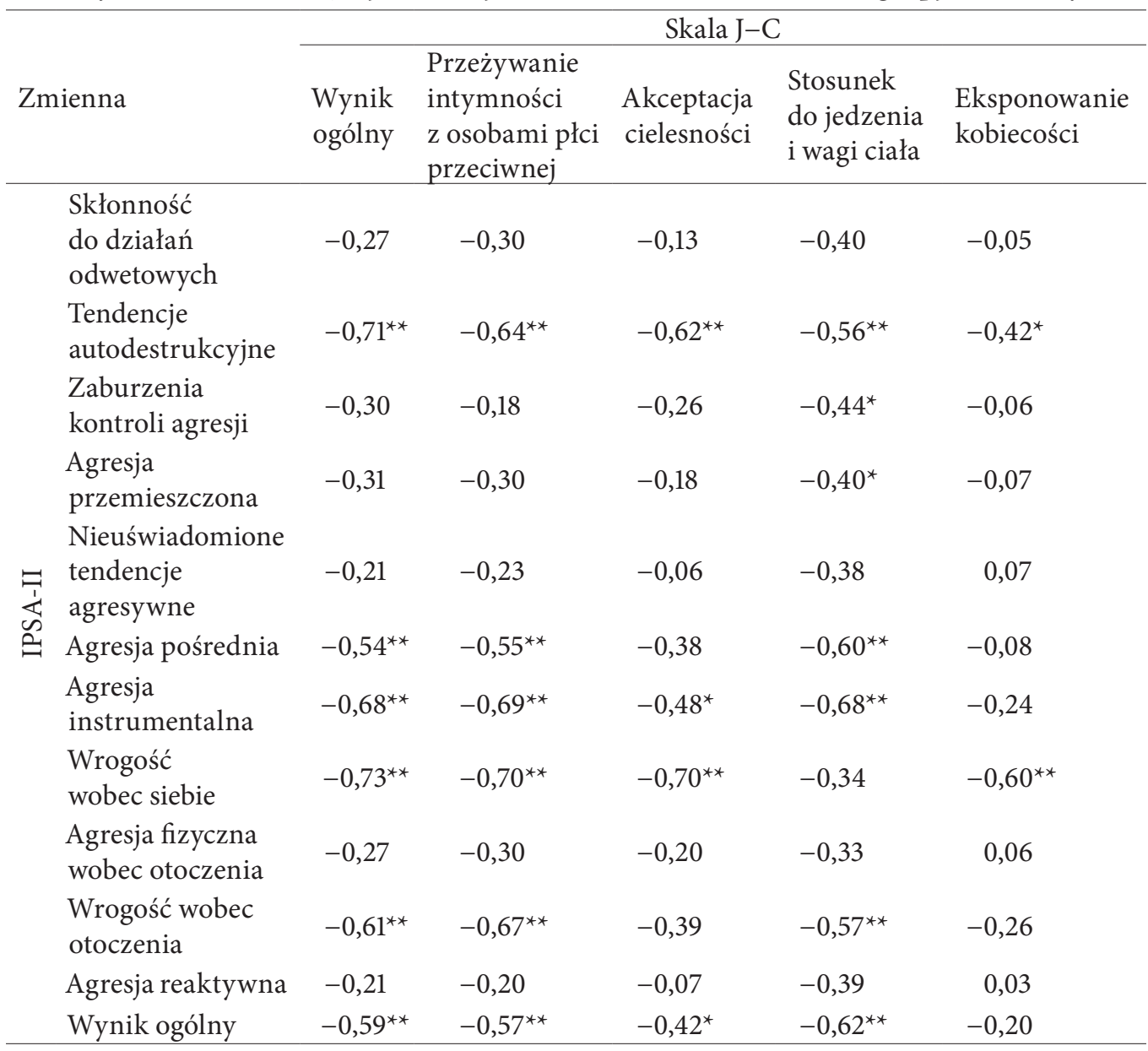

${ }^{\star} p<0,05 ;{ }^{* *} p<0,01$. 
Tabela 4

Korelacje (r Pearsona) między zmiennymi Skali J-C i IPSA-II dla grupy kontrolnej

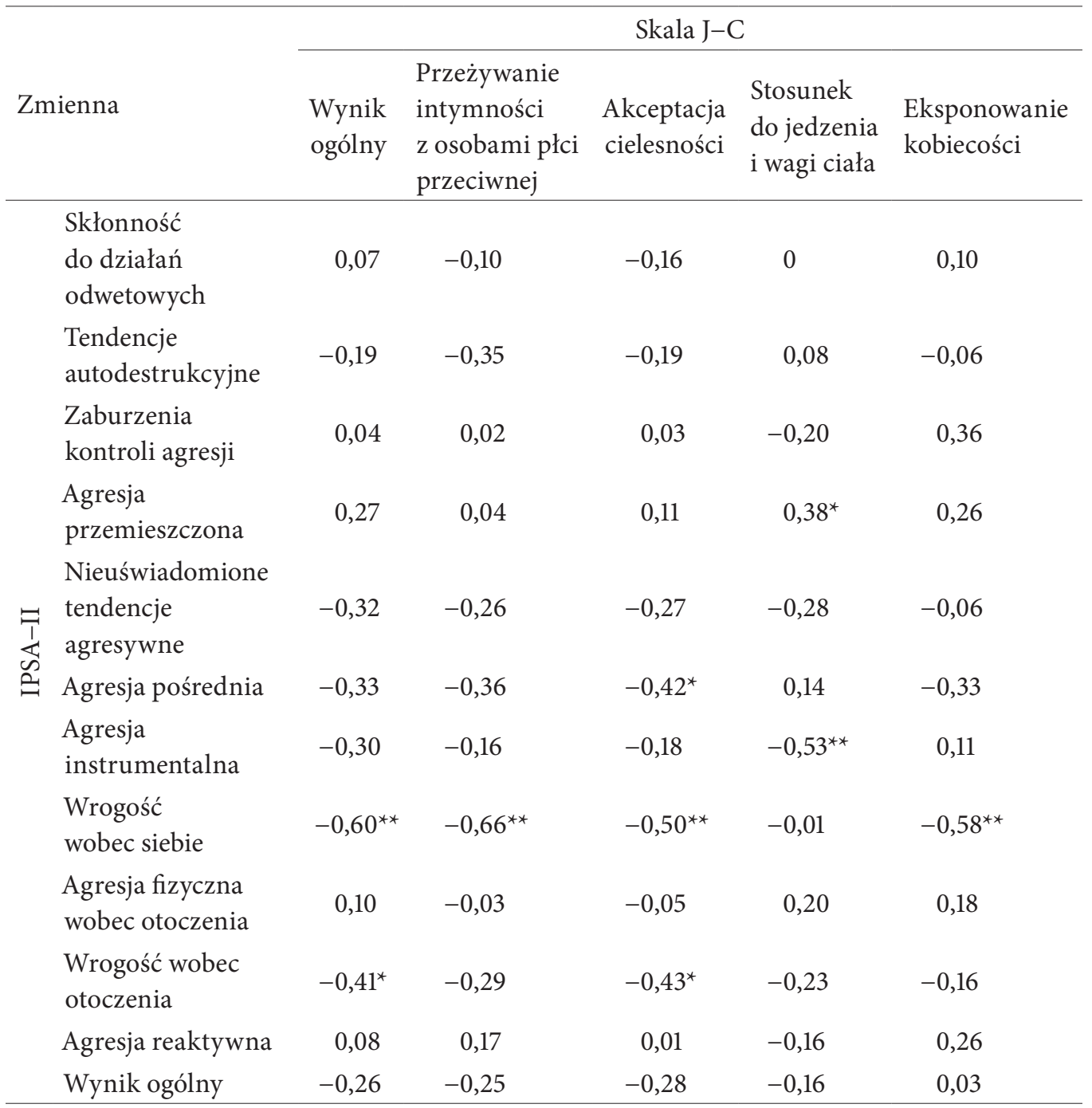

${ }^{*} p<0,05 ;{ }^{*} p<0,01$.

Analiza korelacyjna wyników w grupie kontrolnej pokazuje, że uzyskane istotne współzależności mają w większości charakter ujemny (jedna niska korelacja dodatnia zachodzi między stosunkiem do jedzenia i wagi ciała a agresją przemieszczoną). Wynik ogólny Skali J-C koreluje umiarkowanie z wrogością wobec siebie i wrogością wobec otoczenia. Czynnik przeżywanie intymności z osobami płci przeciwnej koreluje umiarkowanie z wrogością wobec siebie. Czynnik akceptacja cielesności koreluje umiarkowanie z wrogością wobec siebie, wrogością wobec otoczenia i agresją pośrednią. Następnie stosunek do jedzenia i wagi ciała koreluje umiarkowanie z agresją instrumentalną, eksponowanie kobiecości koreluje zaś na poziomie umiarkowanym z wrogością wobec siebie. 
Wyniki w grupie klinicznej, w porównaniu do grupy kontrolnej, pokazują, że nieadaptacyjny wizerunek własnego ciała u kobiet z zaburzeniami odżywiania się współistnieje z całościowym nasileniem agresywności. Jednocześnie taki obraz wiąże się z tendencjami autodestrukcyjnymi, wrogim nastawieniem do siebie i otoczenia, a także z agresją pośrednią i instrumentalną. Z ogólnym natężeniem zachowań agresywnych wiążą się ponadto problemy w relacjach intymnych, niska akceptacja swojej cielesności oraz niewłaściwy stosunek do jedzenia i wagi ciała. Kobiety doświadczają trudności w sytuacjach intymnych z mężczyznami, co wywołuje u nich zachowania agresywne o charakterze instrumentalnym i pośrednim. Ponadto problemy te, podobnie jak nieakceptowanie własnej cielesności oraz lęk przed eksponowaniem kobiecych aspektów, wpływają na przejawianie zachowań autodestrukcyjnych oraz kształtowanie się wrogiej postawy wobec siebie. Z kolei wrogie nastawienie do innych przejawia się w sytuacjach intymnych $\mathrm{z}$ mężczyznami oraz w sytuacjach związanych z jedzeniem. Brak zadowolenia $\mathrm{z}$ własnego ciała może też nasilać skłonność do traktowania działań agresywnych jako sposobu osiągania określonych celów.

Kobiety z zaburzeniami odżywiania się mają niewłaściwy stosunek do jedzenia i wagi ciała, co wiąże się z autoagresją, agresją instrumentalną, pośrednią i przemieszczoną oraz wrogim nastawieniem do otoczenia. Mają one ponadto trudności w kontrolowaniu własnej agresywności.

\section{DYSKUSJA}

Analiza statystyczna wyników badań metodą IPSA-II potwierdziła hipotezę 1., która mówi, iż kobiety z zaburzeniami odżywiania się różnią się od kobiet zdrowych ze względu na zachowania autoagresywne, które są u nich bardziej nasilone. W związku z tym kobiety $\mathrm{z}$ anoreksją i bulimią, częściej aniżeli kobiety zdrowe, przejawiają tendencje autodestrukcyjne, kierując na własną osobę fizyczną agresję w formie zadawania bólu, samouszkodzeń czy prób samobójczych. Są wrogo nastawione do siebie, co przejawia się skłonnościami do samoponiżania, negatywnego osądzania, wyolbrzymiania własnych braków i wad.

Dla potwierdzenia prawdziwości tych wniosków można przytoczyć korespondujące wyniki innych badań na temat zjawiska występowania autoagresywnych zachowań w grupie kobiet z zaburzeniami odżywiania się. Na przykład badania Radziwiłłowicz i Reszki (2008) pokazały, że zachowania autodestrukcyjne (bezpośrednie i pośrednie) częściej są przejawiane przez dziewczęta $z$ anoreksją aniżeli przez ich zdrowe rówieśniczki. Przyjmuje to formę różnych samookaleczeń, głodzenia się, przeczyszczania organizmu i nadmiernego wysiłku fizycznego. Z kolei badania Favaro i Santonastaso (1997) podały, że ogólnie zachowania autodestrukcyjne występują równie często w bulimii, jak i w anoreksji. Jednakże ryzyko myśli samobójczych i prób samobójczych jest większe w bulimii i anoreksji bulimicznej aniżeli w samej anoreksji (Paul i in., 2002). Może to się wiązać z częstszym występowaniem objawów depresyjnych oraz zachowań impulsywnych i obsesyjnych w bulimii psychicznej, w anoreksji zaś - z przekonaniem o własnej doskonałej kontroli wewnętrznej. Niemniej jednak nowsze badania pokazały, iż ponad połowa pacjentek z anoreksją i bulimią ma myśli samobójcze albo rozpatruje odebranie sobie życia (Ruuska i in., 2005).

Literatura przedmiotu wskazuje ponadto na pewne podobieństwa w obrazie zaburzeń odżywiania się i zachowań autoagresywnych, które również mogą być wyjaśnieniem dla współistnienia tychże zjawisk. Zalicza się tu przede wszystkim niewłaściwą relację córki 
z matką (np. Mirucka, 2003, 2005), traumatyczne przeżycia z dzieciństwa, zwłaszcza o charakterze seksualnym (np. Eckhardt, 1998), problemy w okresie adolescencji (np. Kendall, 2002), zaburzenia rozwoju psychoseksualnego (np. Rabe-Jabłońska, Dunajska, 1997), zniekształcony obraz własnego ciała (np. Babiker, Arnold, 2003) i tuszowanie objawów destrukcyjnych zachowań (np. Sakson-Obada, 2009).

W związku z powyższym, kobiety z zaburzeniami odżywiania się nie dostrzegają prawa do życia, a autoagresja (zwłaszcza bezpośrednia) w tej sytuacji jest często wołaniem o pomoc. Taka negatywna postawa wobec własnego życia, awersja w stosunku do własnego ciała, a nawet dysocjacyjne skłonności są właśnie typowymi stanami pojawiającymi się u osób z anoreksją i bulimią, dokonujących samookaleczeń czy też prób samobójczych. Atakowanie ciała, które prawdopodobnie było źródłem poniżenia, bólu czy negatywnych doświadczeń z okresu dzieciństwa, przyczynia się do niewłaściwego rozwoju funkcji opiekuńczej ego (self-care) (Sakson-Obada, 2009). W związku z tym osoba nie ma podstawowych warunków do ochrony samej siebie (JA jest zbyt słabe). Przez zadawanie sobie ran (np. cięcie się, niejedzenie, wymiotowanie) kobiety ponownie doświadczają tych emocji, które występowały podczas traumatycznych wydarzeń w przeszłości. Jednocześnie uwalniają się od nich, oczyszczają swoje ciało i pozbawiają się tego wszystkiego, co nie należy do JA.

Częstsze występowanie autoagresji u kobiet z zaburzeniami odżywiania się niż u kobiet zdrowych można wyjaśnić, odwołując się do literatury przedmiotu. Podejście kliniczne ujmuje zachowania autoagresywne w kategoriach patologii i nieprzystosowania do otoczenia (np. wszelkie zachowania kompensacyjne w anoreksji i bulimii są rozumiane jako nieprzystosowawcze). Ponadto zachowania te są niejako manifestacją zaburzeń charakteru i osobowości (np. Favazza, 1992, za: Babiker, Arnold, 2003) lub zaburzeń kontroli impulsów, np. atak bulimiczny świadczy o utracie samokontroli (np. Pattison, Kahan, 1983, za: Babiker, Arnold, 2003). Z kolei stanowisko systemowe rozumie autoagresję jako zachowanie, którego ukrytym celem jest zwrócenie uwagi innych i uzyskanie pomocy poza systemem rodzinnym. Literatura przedmiotu często podkreśla, że rodziny nastolatków dokonujących samookaleczeń są symbiotyczne i splątane, co również zauważa się w tzw. rodzinach anorektycznych i bulimicznych (Babiker, Arnold, 2003).

Analiza korelacyjna wyników badań skalą J-C i IPSA-II pozwoliła na potwierdzenie hipotezy 2., która mówi, że u kobiet z zaburzeniami odżywiania się zachodzi dodatnia zależność między nieadaptacyjnym obrazem własnego ciała a tendencjami autoagresywnymi. Świadczy to o tym, że kobiety z anoreksją i bulimią mają zaburzone Ja-cielesne i przejawiają zachowania agresywne skierowane przeciw własnemu ciału (a tym samym: przeciw Ja-cielesnemu) oraz są do siebie wrogo nastawione. Istotne znaczenie może tu mieć również nieakceptowanie własnego ciała oraz przejawianie trudności w eksponowaniu swojej kobiecości. Ponadto negatywny stosunek do siebie, a tym bardziej tendencje autodestrukcyjne współistnieją z doświadczaniem lęku w relacjach intymnych z mężczyznami oraz z nieadekwatnym stosunkiem do jedzenia i wagi ciała.

Literatura przedmiotu podaje, że podstawowym składnikiem psychopatologicznego obrazu zaburzeń odżywiania się oraz zachowań autoagresywnych jest zniekształcony wizerunek własnego ciała (czyli zaburzone Ja-cielesne). Liczne badania pokazały, że niewłaściwe spostrzeganie rozmiarów własnej sylwetki zapoczątkowuje i podtrzymuje anoreksję i bulimię (Bruch, 1962; Brytek-Matera, 2008; Rabe-Jabłońska, Dunajska, 1997). Przyczynia 
się to także do ambiwalentnego, a wręcz negatywnego stosunku do własnej cielesności, co wyzwala tendencje autoagresywne u kobiet z zaburzeniami odżywiania się.

Rezultaty badania niniejszego projektu można także wytłumaczyć, odwołując się do nieprawidłowo przebytego procesu separacji-indywiduacji. Jest on bowiem jedną z przyczyn powstawania zaburzeń odżywiania się, zaburzeń obrazu ciała i zachowań autoagresywnych. Skutkiem nieosiągniętej separacji i indywiduacji, według teorii psychodynamicznych, jest powstanie symbiotycznej więzi córki z matką (lub innym znaczącym opiekunem). Wyodrębnianie się u dziecka poszczególnych aspektów struktury JA oraz ich integracja zostają zahamowane. W związku z tym nie rozwija się u niego poczucie tożsamości cielesnej oraz świadomość posiadania swojego ciała, które staje się reprezentantem ciała matki podczas jej fizycznej nieobecności. Dziewczynka, a potem i kobieta przejawiająca zaburzenia odżywiania się, pozbawiona jest naturalnego dążenia do separacji i indywiduacji, co utrudnia naturalne odejście od matki, a to skutkuje wrogim nastawieniem do siebie. W efekcie obraz własnego ciała zostaje zaburzony, a samo ciało staje się źródłem wszelkiej ekspresji oraz obiektem aktów autoagresywnych. Ataki służą nie tylko zadaniu sobie bólu fizycznego, lecz także zniszczeniu ciała, które symbolicznie reprezentuje matkę. Można zatem stwierdzić, iż destrukcja własnego organizmu, a dalej - Ja-cielesnego, które już jest zaburzone, oznacza dla tych kobiet jedyną drogę do osiągnięcia autonomii. Jednocześnie świadczy to o nieświadomym pragnieniu zabicia matki i uwolnieniu się od niej, zwłaszcza jeśli kobieta czuje się przez nią wykorzystana, odrzucona i wzgardzona (Mirucka, 2003, 2005).

Innym wytłumaczeniem dla przejawiania autoagresywnych zachowań i posiadania zaburzonego Ja-cielesnego (a zwłaszcza przeżywanie trudności w relacjach intymnych, nieakceptowanie ciała i blokada w eksponowaniu swojej kobiecości) u badanych kobiet mogą być traumatyczne doświadczenia na tle seksualnym. Literatura przedmiotu podaje, że u ofiar wykorzystywania seksualnego dochodzi często do dysocjacji ciała (Ja-cielesnego) od JA, przez co jest ono traktowane jako „nie-ja”, ale coś zewnętrznego, a także jako źródło lęków, winy i udręki. W związku z tym wszelkie zachowania autoagresywne mogą służyć samounicestwieniu tego, co jest obce, a tym samym - wyzwoleniu się od poczucia winy. W ten sposób ofiary mogą jednocześnie karać swojego prześladowcę, który kiedyś zadawał ból. Jednak z drugiej strony zachowania autoagresywne mogą przywoływać przykre uczucia i emocje z przeszłości, które paradoksalnie mają przypominać osobie, że jest zła, a jej ciało jest przyczyną wszelkich cierpień i niepowodzeń. Najprawdopodobniej z tego powodu (choć z pewnością nie tylko) kobiety z anoreksją i bulimią przeżywają niepokój w intymnych sytuacjach z mężczyznami. Jednocześnie ich choroba może chronić je przed męskim pożądaniem (Babiker, Arnold, 2003; Sakson-Obada, 2009). Ponadto stanowisko psychoanalityczne, mówiąc o lękach natury seksualnej (np. Veldon, 1996), zakłada, że kobiety częściej rozładowują ten lęk, kierując go przeciwko sobie. U kobiet z zaburzeniami odżywiania się może on być związany ze wspomnianym powyżej doświadczeniem wykorzystania seksualnego.

\section{PODSUMOWANIE}

Niniejszy projekt badawczy należy traktować jako przypomnienie problemu związku między obrazem własnego ciała, autoagresją i zaburzeniami dożywiania się. Niemniej jednak 
wyniki zaprezentowane w pracy stanowią wkład w problematykę obrazu ciała i tendencji autoagresywnych $\mathrm{u}$ kobiet $\mathrm{z}$ zaburzeniami odżywiania się. Zaburzone Ja-cielesne wiąże się bowiem z przejawianiem zachowań autoagresywnych. Trudności doświadczane przez kobiety $\mathrm{z}$ anoreksją i bulimią współistnieją $\mathrm{z}$ różnorodnymi tendencjami autoagresywnymi, agresją pośrednią oraz instrumentalną, wrogością wobec siebie i wobec otoczenia. Niniejsze badania mogą być przydatne w psychologicznej pracy z kobietami z zaburzeniami odżywiania się. Terapia (np. poznawczo-behawioralna) może być skoncentrowana na skorygowaniu zniekształconego obrazu własnego ciała oraz na uświadomieniu negatywnych konsekwencji przejawiania różnych zachowań agresywnych i autoagresywnych.

Rezultaty niniejszych badań nie są jednak wolne od ograniczeń. Jedno z takich ograniczeń może stanowić niewielka liczba kobiet w grupie klinicznej. W przyszłości warto zadbać o zwiększenie grupy klinicznej, co niewątpliwie pozwoliłoby na bardziej wnikliwe przyjrzenie się badanym zmiennym. Innym ograniczeniem, częściowo związanym z poprzednim, może być różnica w zakresie świadomości oraz dojrzałości obrazu swojego ciała w grupie klinicznej i kontrolnej. Warto zadbać w przyszłości o większą homogeniczność obydwu grup pod względem wiekowym. Trzeba jednak podkreślić, iż nie jest to metodologiczny błąd, gdyż nawet w badaniach Lewine i Smolak (2004), po początkowym stadium spadku zadowolenia ze swojego ciała w wieku 12-15 lat, wizerunek ciała dochodzi do względnej stabilizacji. Efekty utrzymują się już w późniejszym okresie życia.

\section{BIBLIOGRAFIA}

Babiker, G., Arnold, L. (2003). Autoagresja. Mowa zranionego ciała. Gdańsk: GWP. Bem, S. L. (2000). Męskość, kobiecość. O różnicach wynikających z płci. Gdańsk: GWP. Bilikiewicz, A. (2003). Zespoły psychopatologiczne związane z zaburzeniami procesów fizjologicznych. W: A. Bilikiewicz (red.), Psychiatria (s. 383-389). Warszawa: Wydawnictwo Lekarskie PZWL.

Bruch, H. (1962). Perceptual and conceptual disturbances in anorexia nervosa. Psychosomatic Medicine, 24, 187-194.

Brytek-Matera, A. (2008). Obraz ciała - obraz siebie. Wizerunek własnego ciała w ujęciu psychologicznym. Warszawa: Wydawnictwo Difin.

Brytek-Matera, A. (2011). Postawy wobec ciała a obraz samych siebie u kobiet z zaburzeniami odżywiania się. Badania na gruncie teorii rozbieżności Ja - Edwarda Tory Higginsa. Psychiatria Polska, 45(5), 671-682.

Burstow, B. (1992). Radical feminist therapy: Working in the context of violence. Newbury Park, CA: Sage.

Chojnacka, M., Karczewski, T. (2003). Samouszkodzenia. Kalisz: COSSW.

Cross, L. (1993). Body and self in feminine development: implications for eating disorders and delicate self-mutilation. Bulletin of the Menninger Clinic, 57(1), 41-68.

Dąbrowski, K. (red.). (1985). Zdrowie psychiczne. Warszawa: Wydawnictwo Naukowe PWN. Eckhardt, A. (1998). Autoagresja. Warszawa: Wydawnictwo W.A.B.

Favaro, A., Santonastaso, P. (1997). Suicidality in eating disorders: Clinical and psychological correlates. Acta Psychiatrica Scandinavica, 95(6), 508-514.

Gaś, Z. B. (1987a). Agresja a osobowość w uzależnieniach. Analiza psychologiczna osób uzależnionych od narkotyków, alkoholu i nikotyny. Rzeszów: Wydawnictwo WSP. 
Gaś, Z. B. (1987b). Zrewidowana wersja Inwentarza Psychologicznego Syndromu Agresji - IPSA-II. Przegląd Psychologiczny, 30(4), 1003-1016.

ICD-10 (2000). Klasyfikacja zaburzeń psychicznych i zaburzeń zachowania w ICD-10. Opisy kliniczne i wskazówki diagnostyczne. Międzynarodowa Statystyczna Klasyfikacja Chorób i Problemów Zdrowotnych. Rewizja dziesiąta. Kraków-Warszawa: Uniwersyteckie Wydawnictwo Medyczne „Vesalius” Instytut Psychiatrii i Neurologii.

Józefik, B. (red.). (1999). Anoreksja i bulimia psychiczna. Rozumienie i leczenie zaburzeń odżywiania się. Kraków: Wydawnictwo UJ.

Józefik, B., Pilecki, M. (1999). Obraz kliniczny zaburzeń odżywiania się. W: B. Józefik (red.), Anoreksja i bulimia psychiczna. Rozumienie i leczenie zaburzeń odżywiania się (s. 30-39). Kraków: Wydawnictwo UJ.

Kendall, P. C. (2004). Zaburzenia okresu dzieciństwa i adolescencji. Gdańsk: GWP.

Kołobo, H., Woynarowska, B. (2004). Samoocena masy ciała i odchudzanie się młodzieży w okresie dojrzewania. Przegląd Pediatryczny, 34(3/4), 196-201.

Kowalik, S. (2003). Ja-cielesne. Próba nowego spojrzenia. Polskie Forum Psychologiczne, $8(1-2), 5-29$.

Kozak, A., Kozak, G. (2003). Cechy osobowości i obraz siebie pacjentek z jadłowstrętem psychicznym (anorexia nervosa). Roczniki Psychologiczne, 6, 115-129.

Kruger, D. W. (2002). Psychodynamic perspectives on body image. W: T. Pruzinsky, T. F. Cash (red.), Body image. A handbook of theory, research and clinical practice (s. 30-37). New York: The Guilford Press.

Levine, M. P., Smolak, L. (2004). Body image development in adolescence. W: T. F. Cash, T. Pruzinsky (red.), Body image. A handbook of theory, research and clinical practice (s. 74-82). London and NY: Guilford Press.

Lwow, F., Dunajska, K., Milewicz, A. (2007). Występowanie czynników ryzyka jadłowstrętu psychicznego i bulimii u 18-letnich dziewcząt. Endokrynologia, Otyłość i Zaburzenia Przemiany Materii, 3(3), 33-38.

Mirucka, B. (2003). Ja-cielesne fundamentem osobowości. Polskie Forum Psychologiczne, $8(1-2), 30-40$.

Mirucka, B. (2005). Kwestionariusz Ja Cielesnego (Skala J-C). Przeglad Psychologiczny, 48(3), 313-329.

Paul, T., Schroederm, K., Dahme, B., Nutzinger, D. O. (2002). Self-injurious behavior in women with eating disorders. American Journal of Psychiatry, 159(3), 408-411.

Rabe-Jabłońska, J., Dunajska, A. (1997). Poglądy na temat znaczenia zniekształconego obrazu ciała dla powstawania i przebiegu zaburzeń odżywiania. Psychiatria Polska, 6, 723-738.

Radziwiłłowicz, W., Reszka, N. (2008). Zachowania autodestruktywne u dziewcząt z rozpoznaniem jadłowstrętu psychicznego. Psychiatria, 5(4), 144-155.

Rajewski, A. (2004). Zaburzenia odżywiania. W: I. Namysłowska (red.), Psychiatria dzieci i młodzieży (s. 247-265). Warszawa: Wydawnictwo Lekarskie PZWL.

Ruuska, J., Kaltiala-Heino, R., Rantanen, P., Koivisto, A. M. (2005). Psychopathological distress predicts suicidal ideation and self-harm in adolescent eating disorder outpatients. European Child \& Adolescent Psychiatry, 14(5), 276-281.

Sakson-Obada, O. (2009). Pamięć ciała. Ja cielesne $w$ relacji przywiązania $i w$ traumie. Warszawa: Wydawnictwo Difin. 
Sansone, R. A., Levitt, J. L. (2002). Self-harm behaviors among those with eating disorders: An overview. Eating Disorders, 10, 205-213.

Striegel-Moore, R., Franko, D. (2002). Body image issues among girls and women. W: T. Cash, T. Pruzinsky (red.), Body image. A handbook of theory research and clinical practice (s. 183-191). New York, London: The Guilford Press.

Tokarski, J. (1980). Słownik wyrazów obcych. Warszawa: Wydawnictwo Naukowe PWN.

Veldon, E. (1996). Perversions in men and women. British Journal of Psychotherapy, 14(4), 480-486.

Wciórka, J. (red.). (2008). Kryteria diagnostyczne według DSM-IV-TR. Wydane przez American Psychiatric Association. Wrocław: Elsevier Urban \& Partner, wyd. 1.

Wojtyła, A., Biliński, P., Bojar, I., Wojtyła, C. (2011). Zaburzenia odżywiania u polskich gimnazjalistów. Problemy Higieny i Epidemiologii, 92(2), 343-350.

Wolska, M. (1999). Cechy indywidualne pacjentów z zaburzeniami odżywiania się. W: B. Józefik (red.), Anoreksja i bulimia psychiczna (s. 63-68). Kraków: Wydawnictwo UJ.

Wycisk, J. (2003). Doświadczanie własnej cielesności u kobiet i mężczyzn w kontekście zachowań autodestruktywnych. Polskie Forum Psychologiczne, 8(1-2), 69-77. 